\title{
Fenomena Plagiarisme Mahasiswa
}

\author{
Anisah Hasan \\ Irwan Akib \\ Universitas Muhammadiyah Makassar \\ irwanakib@unismuh.ac.id
}

\begin{abstract}
ABSTRAK
Plagiarisme adalah sebuah realitas yang sering terjadi di kalangan akademis. Penelitian ini bertujuan untuk mengetahui fenomena plagiarisme mahasiswa di kota Makassar, bentuk-bentuk plagiarisme serta faktor penyebab mahasiswa melakukan plagiarisme dalam mengerjakan tugas perkuliahannya. Jenis Penelitian ini adalah metode penelitian deskriptif kualitatif dengan pendekatan fenomenologi, dengan cara penentuan sampel melalu teknik Purposive Sampling dengan memilih beberapa informan yang memiliki kriteria yang telah ditentukan oleh peneliti. Dengan informan berjumlah 16 orang mahasiswa sebagai sampelnya. Hasil Penelitian ini menunjukan bahwa fenomena plagiarisme dikalangan mahasiswa Kota Makassar memang menjamur dan dari berbagai jawaban yang peneliti dapati dari informan semuanya positif menyatakan pernah melakukan tindakan plagiarisme untuk memenuhi tugas perkuliahannya serta Penelitian ini juga bertujuan untuk menggambarkan bentuk-bentuk perilaku plagiarisme yang dilakukan oleh mahasiswa dalam menyelesaikan tugas-tugas perkuliahan. Faktor-faktor penyebab timbulnya perilaku plagiarisme tersebut ada tiga bentuk, yaitu: (1) mengambil tulisan orang lain kemudian diakui sebagai karya sendiri, (2) mengambil ide atau batang tubuh pikiran orang lain untuk selanjutnya dirubah ke dalam bahasa sendiri dan (3) mengambil teks secara keseluruhan tanpa mengubah tulisan maupun menambah dengan analisis maupun komentar apapun. Pemicu terjadinya plagiarisme: (1) perkembangan teknologi informasi dan (2) tingginya intensitas tugas perkuliahan sedangkan alokasi waktu yang tersedia sangat terbatas.
\end{abstract}

Kata Kunci : Fenomena, Plagiarisme, Mahasiswa.

\section{PENDAHULUAN}

Dalam kehidupan manusia pasti ada yang namanya masalah - masalah yang terjadi baik secara sengaja ataupun secara tidak sengaja . Sama halnya dalam mahasiswa ketika mereka mendapatkan tugas dari dosen yang begitu banyak dan memiliki deadline yang sama. Sehingga tidak sedikit mahasiswa melakukan tindakan yang tidak sesuai dengan kaidah semestinya dengan menggunakan cara instan untuk menyelesaikan tugas yang diberikan oleh dosen. Plagiarisme adalah sebuah realitas yang sering terjadi di kalangan akademis, Mahasiswa, dosen bahkan guru besarpun ternyata pernah melakukan plagiarisme yang menjadi awal ketertarikan untuk mendalami lebih lanjut persoalan plagiarisme. Di media elektronik ramai di beritakan mengenai kasus plagiarisme yang di lakukan oleh dosen dan guru besar di beberapa Universitas di Indonesia. Salah satunya 
yaitu di website indonesiabuku.com yang memberitakan beberapa kasus plagiarisme seperti kasus plagiarisme oleh guru besar Universitas Tirtayasa pada pada bulan Februari 2010, kasus plagiarisme yang di lakukan oleh mahasiswa S3 Institut Teknologi Bandung pada tahun 2009, kasus plagiarisme yang terjadi di Universitas Riau yang melibatkan seorang guru besar dan dekan dari Fakultas Keguruan Ilmu Pendidikan, kasus plagiat yang di lakukan oleh tiga dosen Universitas Pendidikan Indonesia (UPI) pada bulan Maret 2012. Banyak kalangan mahasiswa melakukan plagiarisme dalam penyelesaian tugas makalahnya baik tugas secara individu maupun tugas secara kelompok, Ada yang beralasan mereka melakukan plagiarisme karena di kejar deadlinelah, Ada juga yang beralasan malas makanya mereka langsung mengcopy paste tugasnya di internet atau teman kemudian di akui sebagai miliknya, kurangnya ketegasan dari sebahagian pihak dosen tentang plagiarisme sehingga plagiarisme di anggap biasa dan menjadi sangat fenomena di kampus Kota Makassar yang tidak sesuai dengan Visi dan Misi dari kampus itu sendiri.

\section{LANDASAN TEORI}

Menurut Kamus Lengkap Bahasa Indonesia, fenomena di artikan sebagai rangkaian peristiwa serta bentuk keadaan yang dapat di amati dan di nilai lewat kaca mata ilmiah atau lewat disiplin ilmu tertentu. Fenomena terjadi di semua tempat yang bisa diamati oleh manusia. (Kamus Lengkap Bahasa Indonesia : 1997) Ada beberapa definisi menurut para ahli lainnya (dalam Novanta, 2009), yaitu :

1. Menurut Ir. Balza Achmad, M.Sc.E(dalam novanta, 2009) plagiarisme adalah berbuat sesuatu seolah-olah karya orang lain tersebut adalah karya kita dan mengakui hasil karya tersebut adalah milik kita.

2. Menurut Brotowidjoyo (dalam novanta, 2009), plagiarisme merupakan pembajakan berupa fakta, penjelasan, ungkapan, dan kalimat orang lain secara tidak sah

Ada beberapa jenis plagiarisme menurut Ismet Fanany, yaitu: plagiat kata per kata, mengutip kalimat orang lain tanpa mengubah kata-kata tersebut menjadi katakatanya sendiri tanpa mencantumkan sumber yang jelas, menggunakan jalan pikiran orang lain dalam menerangkan pokok pembicaraan, plagiat kata per kata atau frase kunci, apabila ketika kita menulis dalam suatu paragraf dengan meminjam kata-kata kuci dari orang lain tanpa di tandai dengan tanda kutip atau tanpa di tulis dengan kata-kata sendiri (Fanany, 1991: 13-17). Dalam perkembangannya, jenis-jenis plagiarisme bukan hanya itu saja tetapi ada jenis lain yaitu self plagiarism yang di ungkapkan oleh Irving Hexam 
sebagaimana di kutip oleh Henry Soelistyo bahwa self plagiarism yaitu melakukan publikasi terhadap karya sendiri lebih dari satu kali dan mendaur ulang teks untuk di publikasikan lagi tanpa ada pernyataan bahwa karya tersebut telah di daur ulang, kedua tindakan tersebut pada intinya sama yaitu menipu pembaca karena pembaca hanya ingin mengetahui informasi baru ternyata informasi yang diterimanya adalah informasi lama (Soelistyo, 2011:22).

\section{METODE PENELITIAN}

Jenis penelitian yang dilakukan penelitian kualitatif yang bertujuan untuk mengetahui fenomena plagiarisme yang ada dikampus di Kota Makassar. Informan ditentukan secara purposive sampling. Teknik pengumpulan data yaitu observasi, wawancara, dan dokumentasi, kemudian melakukan analisis data kualitatif, serta peneliti juga mengunakan keabsahan data dengan triangulasi data.

\section{PEMBAHASAN}

\section{Fenomena Plagiarisme Mahasiswa Unisuh Makassar}

Dalam ranah dunia pendidikan fenomena plagiarisme memang sering kita jumpai. Untuk menghilangkan plagiarisme sangatlah sulit sebagaimana sulitnya menghilangkan kebiasaan-kebiasaan negatif dalam kehidupan sehari-hari. Plagiarisme atau yang biasa disebut dengan plagiat adalah penjiplakan atau pengambilan karya orang lain dan menjadikan seolah karya tersebut merupakan karangan dan pendapatnya sendiri. Tindakan plagiarisme adalah merupakan perilaku menyimpang yang dilakukan oleh aktor karena penyimpangan sosial menurut lawang (maryati dan suryawati, 2006:122)adalah semua tindakan yang tidak sesuai dengan norma-norma yang berlaku dalam suatu sistem sosial. Sama halnya dengan seorang plagiat tindakan tersebut adalah suatu tindakan yang tidak sesuai dengan norma yang berlaku disuatu masyarkat karena manusia diciptakan mempunyai akal dan pikirannya untuk melakukan sesuatu, jadi tidak sepantasnya seseorang melakukan plagiat dalam karyanya. Fenomena plagiarisme dalam kampuskampus di Kota Makassar untuk saat ini memang sangatlah menjamur dan makin hari makin marak terjadi, melalui wawancara yang peniliti lakukan dengan 16 orang informan. Semuanya positif menyatakan bahwa mereka pernah melakukan tindakan plagiarisme baik dalam tugas perkuliahannya dan ironisnya tindakan mereka tersebut banyak tidak diketahui oleh dosen tetapi ada juga beberapa informan yang mendapat sanksi dari dosen dari 16 orang informan hanya 4 orang saja yang mendapat sanksi dan hukuman. Kata 
plagiarisme berasal dari kata Latin plagiarius yang berarti merampok, membajak. Plagiarisme merupakan tindakan pencurian atau kebohongan intelektual. Plagiarii menurut epik adalah perampok yang suka mencuri atau menculik anak. Jadi bila kita melakukan plagiarisme kita dapat dianggap mencuri otak anak. Namun, karena kita juga mengatakan bahwa itu adalah otak kita, maka sekaligus kita juga berbohong. Jadi orang yang melakukan plagiarisme adalah pembajak dan sekaligus pembohong; karenanya istilah yang eufimistik seperti academic misconduct untuk menyatakan plagiarisme adalah sesuatu yang terlalu lunak atau terlalu manis. The Oxford English Dictionary (1987) mendefinisikan plagiarisme sebagai '.to take and use as one's own the thoughts, writings, or inventions of another.' Banyak lagi definisi tentang plagiarisme yang diajukan, yang kalimat atau kata-katanya dapat berbeda namun intinya sama, yakni penggunaan ide, pikiran, data, kalimat orang lain seolah-olah sebagai miliknya tanpa menyebutkan sumbernya. Definisi berikut dapat menjelaskan makna plagiarisme dengan ringkas "Plagiarisme adalah tindakan menyerahkan (submitting) atau menyajikan (presenting) ide atau kata/kalimat orang lain tanpa menyebut sumbernya" Karena plastisnya pengertian plagiarisme, banyak perguruan tinggi menjabarkan definisi umum tersebut untuk mencegah terjadinya kesalahpahaman atau perbedaan interpretasi terhadap pengertian plagiarisme.

\section{Bentuk-Bentuk plagiarisme}

Secara khusus, tugas utama pendidikan adalah untuk mengekalkan hasil-hasil prestasi kebudayaan, pendidikan pada dasarnya bersifat konservatif (Imran, 1989:12). Pendidikan konservatif ini seperti pada aliran filsafat pendidikan perenialisme dan essensisalisme yang mempertahankan nilai-nilai normative yang telah mapan (status quo). Selain itu, pendidikan mungkin secara tidak sengaja bisa menjadi sumber perubahan kebudayaan (Imran, 1989:63). Perubahan kebudayaan ini, dapat didorong oleh kekuatankekuatan dunia modern. Munculnya dunia modern ini, menjadikan mahasiswa terlena pada situasi yang serba instan dengan adanya kemajuan teknologi. Salah satunya yaitu tindakan mahasiawa menyelesaikan tugas akademik dengan cara instan Copas (copy paste). Sehingga, munculah istilah plagiarisme di lingkungan akademik. Fakta di lapangan bahwa tindakan plagiarisme di kalangan mahasiswa banyak ditemukan pada penyelesaian tugas akademik yaitu paper, makalah, review, dan small research khususnya pada pembuatan field note. Pilihan mahasiswa terhadap penyelesaian tugas akademik merupakan suatu bentuk implentasi adanya tindakan sosial yang dilakukan oleh mahasiswa dalam memilih plagiarisme yang dinilai tepat bagi tugas akademiknya. 
Sehingga, tipe tindakan tersebut jika ditinjau dari penggolongan tindakan yang dilakukan oleh Max Weber tergolong ke dalam tindakan rasionalitas instrumental. Rasionalitas instrumental (sarana-tujuan) yang dikemukakan oleh Max Weber bahwa tindakan yang ditentukan oleh harapan terhadap perilaku objek dalam lingkungan dan perilaku manusia lain, harapan-harapan ini digunakan sebagai syarat atau sarana untuk mencapai tujuantujuan aktor lewat upaya dan perhitungan yang rasional (George dan Douglas, 2009:137). Tindakan rasional instrumental ini, terdapat suatu pemikiran yang dilakukan oleh mahasiswa sebelum memilih cara plagiarisme yang nantinya tepat bagi tugas akademiknya. Pemikiran tersebut tentunya tidak terlepas dari manfaat atau tujuan yang nantinya hendak dicapai oleh mahasiswa. Tujuan tersebut diantaranya adalah agar mahasiswa mempercepat hasil tugas akademiknya dan mendapat nilai baik. Sehingga, pilihan mahasiswa jatuh pada tindakan plagiarisme yang merupakan salah satu alat atau sarana untuk mencapai tujuan. Sarana tersebut juga melalui perhitungan tentang efisiensi dan efektifits untuk mencapai tujuan yang diharapkan mahasasiswa. Lain lagi dengan tindakan rasionalitas nilai yang mengutamakan nilai kebenaran dengan ditentukan oleh tindakan kesadaran. Seperti, menurut Lilik Yunita (2012:134) bahwa mahasiswa menjadikan kegiatan membaca buku sebagai sebuah kebutuhan dalam proses perkuliahan, tetapi sebagian besar lagi menyebutkan bahwa membaca buku menjadi bagian dari hidup mereka, bagian dari hobi mereka yang dilakukan sebagai rutinitas. Membaca buku merupakan suatu nilai perilaku kebenaran untuk menuju keberhasilan dalam proses akademik. Rasionalitas nilai yang digunakan oleh Max Weber bahwa tindakan yang ditentukan oleh keyakinan penuh kesadaran akan nilai perilaku-perilaku etis, estetis, religius, atau bentuk perilaku lain yang terlepas dari prospek keberhasilannya (George dan Douglas, 2009:137). Hal ini, antara rasionalitas instrumental dan rasionalitas nilai saling bertentangan karena dalam penelitian ini, mahasiswa masih lemah dalam minat untuk membaca. Tanpa adanya membaca buku, mahasiswa berperilaku menyimpang untuk memilih plagiarisme sebagai cara instan untuk menyelesaikan tugas akademiknya. Mahasiswa lebih memperhitungkan tentang efisiensi dan efektifitas untuk mencapai tujuan yang diharapkan. Perhitungan inilah yang merupakan essensi dari tindakan rasionalitas instrumental. Faktanya plagiarisme merupakan suatu tindakan rasional pengambilan hasil karya orang lain yang disengaja ataupun tidak disengaja tanpa mencantumkan nama pengarangnya yang diambil karyanya dan dijadikan sebagai hasil karyanya sendiri, tindakan ini melanggar Rasionalitas Plagiarisme suatu Hak Cipta dan Hak Moral. Fenomenanya kasus pelanggaran dari segi Hak Cipta dari status orisinalitas 
karya ilmiah digunakan sebagai acuan hukum, sedangkan dari segi Hak Moral tetap wajib bagi individu untuk menghormati dan menghargai pencipta sebagai penulis yang sebenarnya. Pada penelitian ini, terdapat beberapa pengelompokan dari aspek yang melatar belakangi pembentuk rasionalitas mahasiswa dalam memilih plagiarisme sebagai pilihan yang instan untuk menyelesaikan tugas akademiknya dapat ditinjau dari beberapa faktor. Aspek-aspek inilah yang sering menjadi penyebab terbentuknya rasionalitas dalam melakukan plagiarisme diantaranya.

Pertama, perubahan kebudayaan. Kebudayaan bersifat konstan tetapi juga selalu berubah, tetap dalam arti beberapa elemennya seperti bahasa dan hukum berlanjut terus tanpa perubahan besar selama waktu yang panjang (Imran, 1989:61). Perubahan ini dikarenakan semua elemen-elemenya secara pelahan-lahan mengalami perubahan atau metamorphosis. Perubahan dalam dunia pendidikan ini, ketika mahasiswa menyelesaikan tugas akademiknya dengan melakukan tindakan plagiarisme dapat disebabkan adanya perubahan kebudayaan khususnya pada cultural lag. Bentuk dari cultural lag ini adalah ketidak sesuaian antara perubahan nilai dengan teknologi (Imran, 1989:62). Realitasnya teknologi telah diresapi oleh nilai-nilai karena unsur-unsur teknologi baru dan prosesprosesnya dihubungkan melalui fungsi-fungsi teknologi dengan bentuk-bentuk perbuatan yang dibenarkan oleh individu. Teknologi khususnya pada Gadged mencerminkan nilainilai kepemilikan, kecintaan atas kecepatan akses internet dan teknik pengolahan data. Nilai-nilai tersebut dapat memuaskan mahasiswa dalam proses penyelesaian tugas akademiknya dengan melakukan tindakan plagiarisme dari internet. Menurut James S. Coleman bahwa nilai seseorang dapat diukur melaui tindakan yang akan dilakukannya. teknologi merupakan penyebab terjadinya plagiarisme karena telah membuat mahasiswa semakin terlena pada situasi yang instan tersebut, semua informasi yang diinginkan mahasiswa selalu terpenuhi pada akses internet tersebut.

Kedua, rutinitas mahasiswa modern, hanya sebagai penonton (pasif) dalam proses perkuliahan. Hobi mereka hanya dengan menyibukkan diri untuk tidur, nongkrong, belanja, rekreasi, axis pada status di dunia maya khususnya pada facebook dan kuliah hanya sebagai mencari pacar atau mendapat ijazah. Menurut James S. Coleman bahwa perhatiannya memfokuskan pada tingkat individu yaitu individu yang merupakan tempat dimana intervensi biasanya dilakukan untuk menciptakan perubahan-perubahan sosial. Kecepatan perubahan sosial dan pembentukan karakter budaya akademik yang menyimpang ini dapat meninggalkan pengetahuan dan pengembangan minat belajar 
khususnya membaca buku. Sehingga, mahasiswa dengan sengaja melakukan praktik plagiarisme pada tugas akademiknya.

Ketiga, ditinjau dari aspek struktural yaitu dari segi lemahnya etika akademik dan sanksi plagiarisme, rekomendasi tugas (tema tugas yang berbeda dan banyaknya beban tugas), kewajiban untuk membuat jurnal tanpa ada platihan khusus dan minimnya quota buku di Perpustakaan.

Keempat, tingkat ekonomi menengah yang mengharuskan mahasiswa menjalankan peran ganda yaitu sebagai mahasiswa dan karyawan. Sehingga, peran sebagai mahasiswa telah terpinggirkan dan tidak fokus dalam menyelesaikan tugas akademiknya karena ketika menjalankan peran sebagai karyawan, ia harus stand bay di meja kerjanya.

Kelima, sistem barter juga dapat menyebabkan mahasiswa melakukan tindakan plagiarisme. Hal yang sering dilakukan mahasiswa dengan sistem barter ini terhadap teman dekat (sahabat) dan pacar. Sistem ini hanya mengandalkan sebuah kepercayaan yang penuh terhadap individu satu dengan yang lain. Mahasiswa saling bekerja sama untuk menyelesaikan tugas dengan cara pinjam meminjam tugas atau tukar ide dalam menyelesaikan tugas tersebut. Hal ini, dapat dikatakan bahwa meraka telah melakukan tindakan plagiarisme karena adanya ikatan hubungan tersebut, membuat mahasiswa menjadi terlena untuk selalu meminta bantuan Paradigma kepada pasangannya untuk mengerjakan tugas akademiknya.

Faktor-faktor di atas menunjukkan bahwa semua yang dilakukan oleh mahasiswa memiliki maksud atau tujuan yang hendak dicapai mengarah pada suatu tindakan yang dipilih oleh mahasiswa. Dalam proses tindakan kejahatan plagiarisme yang dilakukan oleh mahasiswa tentunya mempunyai pilihan-pilhan dan pilihan tersebut didasarkan dengan menggunakan pertimbangan-pertimbangan yang mendalam berdasarkan kesadaran, efisiensi dan efektifitas dari nilai lebih atas setiap pilihan yang ada. Misalnya dalam penyelesaian tugas akademik dengan cara plagiarisme untuk mendapat nilai yang bagus dan untuk mempersingkat waktu. Berbagai macam pertimbangan cara atau teknik plagarisme yang dilakukan oleh mahasiswa agar tidak diketahui oleh dosen. Meskipun mahasiswa sudah mengetahui bahwa tindakan tersebut merupakan tindakan yang menyimpang dan melawan kejujuran akademik, namun tindakan tersebut masih tetap dilakukan sampai mahasiswa mendapat keuntungan bagi dirinya sendiri.

\section{Faktor Penyebab Plagiarisme}

Temuan kajian ini secara jelas terdapat bahwa ada dua sebab sebagai pendorong timbulnya perilaku plagiarisme di kalangan mahasiswa Makassar dalam menyelesaikan 
tugas-tugas perkuliahan. Kedua-dua faktor tersebut adalah (perkembangan teknologi informasi dan tingginya volume tugas perkuliahan dari dosen dengan alokasi waktu terbatas). Tidak dapat dibantah lagi bahwa, perkembangan teknologi informasi setidaknya telah membawa dampak yang cukup besar terhadap perubahan cara manusia dalam membuat, menyampaikan dan cara mendapatkan informasi itu sendiri. Kini, tidaklah terlalu sulit jika seseorang ingin mendapatkan informasi yang dikehendaki. Bagaimana tidak, seperti yang dinyatakan oleh salah seorang responden dalam wawancara bahwa semuanya hanya tinggal mengadu kepada "Mbah Google" saja. Maka tidaklah terlalu mengherankan apabila faktor perkembangan teknologi informasi menjadi salah satu penyebab dalam tindakan seseorang melakukan plagiarisme.

\section{KESIMPULAN}

Dalam penelitian ini telah berhasil mengungkapkan kalau makassar masih banyak mahasiswa yang melakukan tindakan plagiarisme dalam pembuatan tugas perkuliahanmya dan Penelitian juga telah berhasil mengungkap bentuk-bentuk perilaku dan faktor-faktor penyebab timbulnya plagiarisme di kalangan mahasiswa dalam menyelesaikan tugas-tugas perkuliahan yang diberikan dosen. Penelitian menyimpulkan bahwa terdapat tiga bentuk tindakan plagiarisme yang dilakukan oleh mahasiswa yaitu:

1. Mengambil ide orang lain kemudian para mahasiswa mengakui hal tersebut sebagai karya atau buah dari pemikiran mereka sendiri

2. Mengambil tulisan orang lain kemudianpara mahasiswa memparafrasakan tulisan orang lain tersebut dengan kalimat sendiri, walaupun ide atau batang tubuh tulisan tidak berubah.

3. Mengambil teks secara keseluruhan, selanjutnya tulisan tersebut ditulis kembali tanpa ada tambahan apapun dari mahasiswa.

Hasil penelitian ini juga menyimpulkan bahwa terdapat dua faktor penyebab timbulnya perilaku plagiarisme di klangan mahasiswa tersebut yaitu.

1. Perkembangan teknologi informasi seperti media elektronik sehingga telah memudahkan para mahasiswa mendapatkan bahan-bahan perkuliahan dari sumbersumber tersebut.

2. Tingginya beban tugas perkuliahan yang diberikan oleh dosen, budaya instan dan tidak cukupnya waktu yang tersedia telah telah menggiring mahasiswa agar berperilaku plagiarisme. 


\section{DAFTAR PUSTAKA}

Agustang, Andi. (2011). Filosofi Research ( Dalam Upaya Pengembangan Ilmu). Makassar.

Depdikbud. (1997). Kamus Besar Bahasa Indonesia. Jakarta : Balai Pustaka.

Depdikham. (2013). Undang-Undang Perlindungan HAKI (Hak Atas Kekayaan Intelektual). Bandung : Citra Umbara

Fanany, Ismet. (1991), Plagiat-plagiat di MIT: Tragedi Akademis di Indonesia, Pustaka Pelajar, Yogyakarta

Indonesia buku. (2010), "Inilah Kasus-kasus Penjiplakan Akademisi Indonesia pada 2010", diakses hari rabu tanggal 23 maret 2015 pukul 15.31 WITA dari: http://indonesiabuku.com/?p=10735

Journey,Shindoh. (2009). Kebiasaan copy paste dikalangan civitas akademis. (https://shindohjourney.wordpress.com/2010/06/13/kebiasaan-copy-paste-dikalangan-civitas-akademis/ diakses pada tanggal 22 maret 2015 Pukul 01.00 WITA)

Kementerian Pendidikan Nasional. (2010), Peraturan Pemerintah Pendidikan Nasional no. 17 tahun 2010 tentang Pencegahan dan Penanggulangan PlagiatdiPerguruan Tinggi, dari: http://luk.tsipil.ugm.ac.id/atur/Permen17-2010.pdf diakses tanggal 21 Maret 2015 pada pukul 09.00 WITA

M.Setiady,Elly, dkk. (2006) .Ilmu Sosial dan Budaya Dasar. Jakarta : Kencana.

Ma'ruf, Syafi'i. (2013). Perilaku Beragama Mantan PSK (Studi Kasus Di Ppskw Mattirodeceng Kelurahan Sudiang Raya Kecamatan Biringkanaya)

Moleong, Lexi J. (2007). Metode Penelitian Kualitatif. Penerbit PT RemajaRosdakarya, Bandung.

Novanta,Audy. (2009). Pendeteksian Plagiarisme Dokumen Teks dengan Menggunakan Algoritma Smith-Waterman, (http://repository.usu.ac.id, diakses 24 maret 2015).

Poloma, Margaret M. (2010). Sosiologi Kontemporer. PT Rajagrafindo Persada, Jakarta. : Prasada Publisher.

Ritzer, George dan Goodman, Douglas J. (2009). Teori Sosiologi Modern; Dari Teori Sosiologi Klasik Sampai Perkembangan Mutakhir Teori Sosiologi Postmodern. Yogyakarta: Kreasi Wacana.

Ritzer, George dan Goodman, Douglas J. (2011). Teori Sosiologi Modern, Kencana, Jakarta.

Salim, Agus. (2006), Teori dan Paradigma Penelitian Sosial - Buku Sumber Untuk Penelitian Kualitatif, Tiara Wacana, Yogyakarta. 
Soekanto, Soerjono. (2012). Sosiologi Suatu Pengantar. Jakarta: PT Rajagrafindo

Soelistryo, Henry. (2011). Hak Cipta Tanpa Hak Moral, PT Rajagrafindo Persada, Jakarta.

Soelistryo, Henry. (2011). Plagiarisme: Pelanggaran Hak Cipta dan Etika, Kanisius, Yogyakarta.

Sudigdo, Sastroasmoro. (2007). Beberapa Catatan Tentang Plagiarisme. Majalah Kedokteran indonesia, Volum : 57, Nomor: 8, agustus 2007, 239-244

Suganda, Aziz. (1997). Sosiologi 1. Jakarta: PT. Balai Pustaka.

Sugiyono. (2013). Memahami Penelitian Kualitatif. Bandung : PT. Alfabeta

Sunarto, Kamanto. (2004). Pengantar Sosiologi. Jakarta: Fakultas Ekonomi Universitas Indonesia

Suprapto. (2013). Metodelogi Penelitian Ilmu Pendidikan dan Ilmu-Ilmu Pengetahuan Sosial. Jakarta : PT.Buku Seru.

Tiro, Muhammad Arif. (2005). Metode Penelitian Sosial-Keagamaan. Penerbit 